\title{
College English Reading Teaching from the Perspective of Modern Information Technology
}

\author{
JingWang ${ }^{1}$ Qin Wang ${ }^{2, *}$ \\ ${ }^{1}$ Leshan Normal University, Leshan 614000, Sichuan, China \\ ${ }^{2}$ Guilin University of Electronic Technology Beihai Campus, Beihai 536000, Guangxi, China \\ Corresponding author and e-mail: 283252764 @qq.com
}

\begin{abstract}
It needs a lot of language input and output for College English reading teaching. Frequent interaction between teachers and students can make English learning more meaningful. The course of College English reading is teachercentered neglecting the dominant position of students and having the single teaching content. It is not ideal for the teaching effect. Modern information technology has strong technical and theoretical advantages, which application in College English reading teaching will bring innovation and convenience to college English reading teaching.
\end{abstract}

Keywords: College English reading teaching, Modern information technology, Interaction between teachers and students, Innovation and convenience.

\section{INTRODUCTION}

With the development of information society, modern technology has changed people's way of life, work and education. Modern information technology has influenced people's every aspect of life. Western countries first used information technology to reform education system and methods, and achieved great success. Now, the use of modern information technology has become an educational trend. Under the impact of modern information technology, the traditional teaching mode of blackboard, teaching materials and chalk has undergone great changes. The teaching method of simple explanation and learning is single, time-consuming, and the effect is not ideal. The use of modern information technology has not only brought convenience to teaching time, but also changed the relationship between teachers and students. Great changes have taken place in teaching mode, teaching means and teaching methods. The mission of modern educators has also been changed into how to make education truly benefit every learner through modern technology.

\section{RESEARCH BACKGROUND}

Modern information technology is a comprehensive system of modern education methods, means and technologies that organically integrate modern information technology and modern education theories and apply them to the education and teaching practice [1]. The wide use of modern information technology also means the change of teaching means and learning strategies. The educational services and tools provided by modern information technology are diversified: interactive whiteboard, projector, smart classroom, computer or laptop, smart phone, touch tablet, etc. The organic integration of modern information technology and College English is in line with the core concept of modern education theory. The integration is a profound change of Modern College English classroom teaching mode, and is an effective way to improve college English teaching effect and talent training quality [2].

The application of these technologies means the change of teaching methods, teaching contents and learning methods, which can construct the classroom teaching with students as the main body, activate the classroom atmosphere and optimize the teaching contents. The integration of modern information technology and education can stimulate students' interest in learning and enhance their initiative and enthusiasm in learning. The use of information technology can organically combine text and audiovisual, and make the classroom vivid. The teaching content is rich, not limited by time. Indirect knowledge has become direct knowledge. Students have strong interest in learning, and the teaching effect is obvious. 


\section{INTEGRATION OF MODERN INFORMATION TECHNOLOGY AND COLLEGE ENGLISH READING TEACHING}

The current situation of College English reading teaching is not optimistic. The course of College English reading is teacher-centered, neglecting the dominant position of students. There is less interaction between students and teachers, and in class teachers just teach and students just learn. Many teachers still focus on teaching materials with single teaching content. The teachers teach more students every day, and can't guide each student alone. Therefore, the teaching effect is poor. It is vital to integrate the modern information technology and College English reading teaching

It is an important issue for College English teachers and researchers to actively explore the deep integration of modern information technology and College English reading teaching. In the actual teaching, the multimedia technology, digital image technology, artificial intelligence technology and virtual reality simulation technology and other modern information technology are applied to the pre-class teaching design, in-class teaching process and after-class teaching evaluation, so as to ensure the realization of teaching informatization in education.

\subsection{The Pre-class Teaching Design}

Modern information technology integrates computer and network information, and works with education theory to produce a reasonable education system and achieve the goal of education optimization. Making multimedia teaching courseware before class and searching some static pictures, dynamic pictures, audio pictures and videos related to classroom teaching content on the Internet, these ways of intuitive classroom introduction effectively improves learners' learning enthusiasm. Modern information technology which are applied to all aspects of teaching design can help teachers to clarify the ideas, improve the speed and strengthen the effect of teaching design. Generally speaking, a complete instructional design includes seven links: analysis of teaching objectives, analysis of teaching contents, analysis of learners, selection of teaching media, determination of teaching strategies, arrangement of teaching steps and activities, and evaluation of instructional design results [3]. The application of modern information technology in teaching not only makes rational use of various teaching resources, but also improves students' comprehensive quality and ability.

MOOC online class [4] and online micro class [5], as well as flipped class, are new teaching forms of modern technology to teach classroom knowledge. MOOC, namely massive open online course, originated in 2012, and then developed rapidly. Flipped classroom mode is that teachers present information or (in the case of language learning) language items in transmissiontype input sessions and then the students go home and do practice exercises and tasks by themselves as homework. In such a scenario, classrooms are where people learn things and home is where they practice them [6]. In the classroom, teachers have enough time to participate in students' autonomous learning activities and writing [7]. These new network teaching methods soon brought about the change of educational ideas and methods. With the application of modern information technology, the face-to-face learning of teachers and students is organically combined with the online learning of students, which enables students to realize autonomous learning and personalized learning.

\subsection{The In-class Teaching Process}

In the teaching process, the modern information technology will be effectively integrated into teaching, to improve the quality and efficiency of teaching. The use of modern information technology not only creates and optimizes new teaching and learning models, but also cultivates the practical and innovative abilities of educators and learners. It makes abstract knowledge visualized and concrete, and realizes the organic combination of people, sound and pictures. It enables learners to exercise their thinking ability and grasp the language information in a relaxed and pleasant communication atmosphere. Modern information technology cultivates students' knowledge management ability, man-machine communication ability, selflearning and lifelong learning ability, and critical thinking ability. These four skills can help students examine problems from a broader perspective, make comprehensive and three-dimensional analysis and judgment, obtain more solutions, and improve their ability to solve problems [8].

\subsection{The After-class Teaching Evaluation}

Teaching evaluation is an important part of a class. Teaching evaluation is not only an important basis for teachers to obtain teaching feedback, improve teaching management and ensure teaching quality, but also an effective means for students to adjust learning strategies, improve learning methods, improve learning efficiency and achieve good learning results [9]. Therefore, under the background of modern information technology, College English curriculum should establish diversified evaluation subjects, evaluation methods, content and purpose, change the traditional single evaluation mode, make teaching evaluation pay more attention to dynamic teaching process, make classroom evaluation a part of teaching steps, and make formative evaluation and teaching steps closely combined. Through teaching evaluation, teachers and students are 
clearer about teaching objectives, and know how to achieve teaching objectives. Under the guidance of teaching objectives, teachers will reflect on teaching activities to ensure that teaching objectives are achieved in teaching activities and cultivate students' selfevaluation ability and learning ability.

\section{APPLICATION OF MODERN INFORMATION TECHNOLOGY IN COLLEGE ENGLISH READING TEACHING}

The application of modern information technology in College English reading teaching is the inevitable requirement of the reform of College English teaching methods. Teachers use modern information technology, constantly update English teaching methods, enrich English teaching resources and increase English learning methods, which can effectively improve students' comprehensive language ability. Based on the characteristics of College English and the cognitive level of students, this paper introduces the application of modern information technology in pre-class teaching, in-class teaching and after-class teaching by taking text A fail for tomorrow in unit 8 Protecting our environment [10] as an example.

\subsection{The Pre-class Activities}

Before class, the teacher analyzes the key and difficult points of teaching based on the situation of students. This text material is taken from unit 8 "protecting our environment" [11-12] of College English comprehensive course 2. This material is the preface of silent spring. It mainly tells that after people came to live in the village, the harmony between the village and the surrounding environment was broken. The epidemic spread. Animals and people died inexplicably. Hens could not hatch chickens. Apple trees bloomed, but no bees pollinated. Powder like snow falls on roofs, lawns, fields and streams. The theme of the text is environmental pollution and environmental protection. After nearly a semester of study, students can express the words, phrases and sentences related to the environment. With the help of teachers, students can understand the text information and analyze the text structure, and obtain more information related to the theme. The teaching objectives are as follows: to understand the causes of village changes and what measures can be taken to protect the environment; After class, students can make a poster about environmental protection according to what they have learned; Emotional guidance to students to know the importance of protecting the environment. In the future of daily life, students protect the environment, love the earth. The teachers prepare a video about malaria and silent spring. Students watch the video before class and learn with some questions: To learn some facts and views about
DDT; To know the bad effects of overuse of DDT; To understand the main idea of Silent Spring; To know how the text is organized; To develop the students' reading ability through skimming and scanning; To develop the students' listening and speaking ability through listening and talking.

\subsection{The In-class Teaching}

The classroom teaching is mainly composed of prereading, while-reading and post-reading.

A good introduction (pre-reading) is the key to a successful class. The application of modern information technology can effectively arouse the enthusiasm of students, improve the interest of the classroom and the efficiency of curriculum learning. Modern information technology can create a relaxed and pleasant learning environment and encourage students to actively participate in learning activities. There are some ways to introduce the materials: lead-in with pictures, lead-in with videos, lead-in with songs, lead-in with stories. For the lead-in with pictures, the teachers use information technology to search two groups of pictures on the Internet. One group is the picture of harmonious human and nature, that is, the picture of decades ago when the environment was not destroyed. One group is the picture of human beings' pursuit of high-speed development and the destruction of the environment. The two groups of pictures give students a strong visual and emotional impact. This is also closely related to the content of the text to be learned. For the lead-in with videos, the teachers play videos of environmental damage, let students realize the urgency of environmental protection. Everyone should take good care of the earth and protect the environment. For the lead-in with songs, the teachers play songs on environmental protection, supplemented by videos or pictures on environmental protection, to deepen students' understanding of environmental protection. For the lead-in with stories, the teacher divides the students into several groups before class. The students preview the text and basically understand the content of the text. At the beginning of the class, one representative from each group tells the story of the text content in English. This kind of introduction mainly exercises students' learning ability, oral communication ability and listening ability.

After the pre-reading, it is the while-reading. The teachers use PPT to combine organically pictures, sounds and words. First, the teachers guide the students to scan the article quickly and answer the question: what do you think spring should be like? Why is spring silent? What do the roadsides look like now? When answering questions, students can perfect the answer, and teachers can also supplement and make comments. Then the students read the text intensively. Read the text in groups and show the changes before and after the 
village in the form of painting, and describe the changes in English.

On the basis of students' understanding of text information, the teachers design activities to guide students to realize language transfer and practical application during the post-reading. Students draw mind maps or make posters to appeal and publicize the relevant contents of environmental protection. Then teachers use multimedia to summarize and consolidate the content of this lesson.

\subsection{The After-class Evaluation}

The After-class evaluation is generally a step that the teachers are easy to ignore. Teaching evaluation is not a single process that the students complete the homework. It can be statistical analysis, testing, the growth files, special reports, presentation, etc. The teaching evaluation includes teachers' evaluation of students, students' evaluation of teachers, and evaluation of each step of teaching. The application of modern information technology provides convenience for teaching evaluation. Through the teaching evaluation, the teachers can know the students' learning situation and learning progress in real time. The teachers can understand whether the teaching objectives are clear and whether the students have mastered the key and difficult points in teaching. The teachers can adjust the teaching content and teaching progress according to the situation of the student.

\section{CONCLUSIONS}

Modern teaching technology improves the timeliness of teaching information dissemination through multimedia and network. It needs to rely on modern information technology for the innovation and development of College English reading teaching. It can effectively improve the overall efficiency of classroom teaching, teachers' teaching ability and students' ability to learn and grasp the new knowledge, and cultivate students' autonomous learning ability and innovative consciousness through the integration of modern information technology and College English reading teaching. Modern information technology makes the teaching evaluation more accurate, so that the teachers can timely understand the situation of students and adjust teaching arrangements. Modern information technology has played an effective role in all aspects of College English teaching and greatly improved the teaching effects. Modern information technology makes the learning of teachers and students more interesting, autonomous, personalized and effective.

\section{ACKNOWLEDGMENTS}

This work is supported by the Undergraduate Education Reform Project of Guangxi Higher Education in 2020 (Grant No. 2020JGA182); the second batch of Production-learning-Researching Cooperative Education Project of the Ministry of Education in 2019 (Grant No. 201902079011), and the Basic Scientific Research Ability Improvement Project for Young and Middle-aged Teachers of Guangxi's University (Grant No. 2021KY0184).

\section{REFERENCES}

[1] Zhiqiang $\mathrm{Hu}$, Huafeng Guo. "Internet Plus" and Modern Information Technology Research in Big Data Technology Environment [J]. The Chinese Journal of ICT in Education. 2016. (15) 10-12.

[2] Hui Song. Strategies for College English Teachers' Professional Development Under the Background of Modern Educational Information Technology [J]. Higher Education Forum. 2019(07) 66-68

[3] Zhaojun Li, Meifeng Li. Modern Information Technology and High School History Teaching [M]. Peking: Higher Education Press. 2012

[4] Chen xiaogeng, Wang Dingming. Analysis on the Development Process and Main Characteristics of MOOC $[\mathrm{J}]$. Modern Information Technology. 2013(11):5-10.

[5] Yichuan Zhang, Yangyi Qian. Progress in the Construction and Application of "Micro Lesson" Resources at Home and Abroad [J]. Journal of Distance Education. 2013 (6) : 26-33.

[6] Jeremy Harmer. The Practice of English Language Teaching [M]. Pearson Education Limited. 2015.

[7] Baker J. Wesley.The classroom flip: using web cou rse management tools to become the guide by the si de

[A] In: Chambers, Jack A., Ed. Selected Papers fro $\mathrm{m}$ the 11thInternational Conference on College Tea ching and Leaming(C).Florida:Florida Community Coll.Jacksonville,2000:3.

[8] Tony Bates. Teaching in a Digital Age [M]. Peking: China Radio and Television University Press. 2016. 123

[9] The higher education Department of the Ministry of Education. College English Curriculum Requirements [M]. Shanghai: Shanghai Foreign Language Education Press, 2007:7-8.

[10] Yinhua Li, Deming Wang. New college English (Second Edition) Integrated course 2 [M]. Shanghai: Shanghai Foreign Language Education Press. 2014.05(2). 
[11] Peiying Ji, Xiaozhen Wu, Ye Fan. New college English (Second Edition) Integrated course 2(Teacher's Manual) [M]. Shanghai: Shanghai Foreign Language Education Press. 2014.05(2).

[12] Na Sun, Jiapei Li. Exploration on Process Evaluation of College English Teaching in Rotating Classroom Mode [J]. Atlantis Press. 2018(194) 